\title{
Effect of low-level LASER and neural mobilization on nociceptive threshold in experimental sciatica*
}

\author{
Efeito do LASER de baixa potência, da mobilização neural e da sua associação sobre o limiar \\ nociceptivo em ciatalgia experimental
}

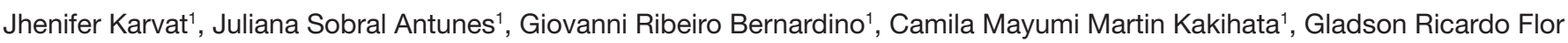
Bertolini $^{1}$

${ }^{*}$ Received from State University of Western Paraná, Cascavel, PR, Brazil.

\section{ABSTRACT}

BACKGROUND AND OBJECTIVES: There are few studies in the literature especially reporting the effects of LASER associated to neural mobilization for sciatica. This study aimed at evaluating the effect of low-level LASER with wavelength of 830 $\mathrm{nm}$ and fluency of $4 \mathrm{~J} / \mathrm{cm}^{2}$, of neural mobilization and of their association to decrease pain.

METHODS:Sample was made up of 28 Wistar female rats, separated in four groups: G1 (placebo); G2 (neural mobilization); G3 (LASER); G4 (neural mobilization and LASER), being that all groups were submitted to sciatic nerve compression. Treatment was performed in the $3^{\text {rd }}, 5^{\text {th }}, 7^{\text {th }}, 10^{\text {th }}, 12^{\text {th }}$ and in the $14^{\text {th }}$ postoperative days. To evaluate nociception an analgesimeter was applied both to injury site and the plantar region of right hind paw. Evaluation moments were AV1 (pre-injury); AV2 ( $3^{\text {rd }}$ postoperative day before treatment); AV3 ( $4^{\text {th }}$ postoperative day); AV4 ( $7^{\text {th }}$ postoperative day), AV5 (10 ${ }^{\text {th }}$ postoperative day) and AV6 (14 $4^{\text {th }}$ postoperative day) before treatment; and AV7 ( $15^{\text {th }}$ postoperative day).

RESULTS: At evaluation sites, there has been no statistically significant difference among groups, but in comparing evaluations there has been significant difference where AV1 values were higher as compared to remaining evaluations.

CONCLUSION: Low-level LASER with wavelength of $830 \mathrm{~nm}$ and fluency of $4 \mathrm{~J} / \mathrm{cm}^{2}$, neural mobilization and the association of both techniques were not effective to increase nociceptive threshold to pressure of female rats submitted to experimental sciatica. Keywords: Low level laser therapy, Nervous compression, Pain measurement.

1. State University of Western Paraná, Course of Physiotherapy, Cascavel, PR, Brazil.

Submitted in November 25, 2013

Accepted for publication in July 22, 2014.

Conflict of interests: none.

Correspondence to:

Gladson Ricardo Flor Bertolini

Laboratório de Estudo das Lesóes e Recursos Fisioterapêuticos da UNIOESTE

Rua Universitária, 2069 - Jardim Universitário

85819-110 Cascavel, PR, Brasil.

E-mail: gladson_ricardo@yahoo.com.br

(C) Sociedade Brasileira para o Estudo da Dor

\section{RESUMO}

JUSTIFICATIVA E OBJETIVOS: Há uma carência na literatura relatando, principalmente, os efeitos do LASER associado à mobilização neural na ciatalgia. $\mathrm{O}$ objetivo deste estudo foi verificar o efeito do LASER de baixa potência, com comprimento de onda $830 \mathrm{~nm}$ e fluência de $4 \mathrm{~J} / \mathrm{cm}^{2}$, da mobilizaçáo neural e da sua associação, na redução da dor.

MÉTODOS: A amostra foi composta por 28 ratas Wistar, separadas em quatros grupos: G1 (placebo); G2 (mobilização neural); G3 (LASER); G4 (mobilização neural e LASER), sendo que, todos os grupos foram submetidos à constriçáo do nervo isquiático. $\mathrm{O}$ tratamento ocorreu no $3^{\circ}, 5^{\circ}, 7^{\circ}, 10^{\circ}, 12^{\circ}$ e no $14^{\circ}$ dia de pós-operatório. Para a avaliação da nocicepção foi utilizado um analgesímetro, aplicado tanto no local da lesão como na região plantar da pata posterior direita. Os momentos de avaliação foram: AV1 (pré-lesão); AV2 (3º dia de pós-operatório antes do tratamento); AV3 (4º dia de pós-operatório); AV4 (70 dia de pós-operatório), AV5 (10 dia de pós-operatório) e AV6 (14º dia de pós-operatório) aconteceram antes do tratamento; e a AV7 (15 dia de pós-operatório).

RESULTADOS: Nos dois locais de avaliação, constatou-se que não houve diferença estatisticamente significativa entre os grupos, mas, na comparação entre as avaliações, houve diferença significativa, cujos valores de AV1 foram maiores do que aqueles encontrados nas demais avaliaçóes.

CONCLUSÁO: O LASER de baixa potência com comprimento de onda de $830 \mathrm{~nm}$ e fluência de $4 \mathrm{~J} / \mathrm{cm}^{2}$, a mobilizaçáo neural e a associação das duas técnicas, não foram eficazes para aumentar o limiar nociceptivo à pressão de ratas submetidas à ciatalgia experimental.

Descritores: Compressão nervosa, Medição da dor, Terapia a laser de baixa potência.

\section{INTRODUCTION}

Pain induced by tissue injury is considered a body protection mechanism which may be triggered by different stimuli which depolarize pain receptors (nociceptors), and pain perception and body response to painful stimuli are called nociception ${ }^{1}$.

Peripheral nerves are constant targets for crush, compression and 
transection injuries. Such injuries result in pain, decrease or loss of sensitivity and mobility in the innervated territory ${ }^{2}$. Sciatica is among the most common affections ${ }^{3}$.

Sciatica involves pain irradiating to gluteus, hips and lower limb extremities. Pain is in general associated to tingling, numbness, stiffness or weakness of lower limb muscles innervated by the sciatic nerve. It may have sudden onset and may persist for days or weeks ${ }^{4}$, being its primary causes: herniated discs, traumas, infections, inflammations which may affect the nervous system, vascular compression, tumors, congenital abnormalities, lumbar canal stenosis, degenerative processes and piriformis syndrome ${ }^{3}$. There are numerous cause-dependent therapies for this disorder. Among them there are initial rest, drugs and physiotherapeutic techniques, such as osteopathic treatment, physical exercises, postural orientations, flexibility training and electrothermophototherapeutic resources. When conservative therapies fail, surgical treatment is recommended ${ }^{4}$.

With regard to electrothermophototherapeutic resources to relieve symptoms, one may mention low-level LASER due to its possible anti-inflammatory, analgesic, repair and tissue healing effects. The analgesic effect may be explained by muscle relaxation, opioid mechanisms and may be obtained by interrupting arachidonic acid conversion into prostaglandins, in addition to increasing local blood flow and promoting the resorption of inflammatory exudates, favoring the elimination of algogenic substances such as bradykinin, histamine and acetylcholine, leading to decreased inflammation and pain 5 .

Another technique is neural mobilization, manual therapy method used by physiotherapists to treat patients with neural pain, such as sciatic nerve compression, being considered an effective noninvasive therapy to improve quality of life of neuropathic pain patients ${ }^{6}$. Its objective is to impose to the nervous system higher tension through certain postures to afterward apply slow and rhythmic movements directed to peripheral nerves and spinal cord, providing improvement in nervous impulse conductibility ${ }^{7}$. This way, the intention is to reestablish peripheral nervous system mobility, promoting nervous tissues homeostasis and, as a consequence, symptoms improvement ${ }^{8,9}$.

Because sciatica is a painful syndrome of high incidence and notwithstanding the association of both techniques (LASER and neural mobilization) being widely used in the clinical practice, there are still few literature reports on the effects on this dysfunction, thus justifying studies with such approach. However, studies in humans have the inconvenient of standardizing the type of injury, being better evaluated in experimental studies.

This study aimed at evaluating the effect of low-level LASER, with wavelength of $830 \mathrm{~nm}$ and fluency of $4 \mathrm{~J} / \mathrm{cm}^{2}$, associated or not to neural mobilization, on the nociceptive threshold of female rats submitted to experimental sciatica.

\section{METHODS}

This is an experimental and transversal study carried out in the laboratory of study of injuries and physiotherapeutic resources, State University of Western Paraná (UNIOESTE), Cascavel campus.
Sample was made up of 28 female Wistar rats, 10 weeks, mean weight of $301.71 \pm 22.76 \mathrm{~g}$, which were maintained in standard polypropylene boxes, in environment with temperature of $23 \pm 1^{\circ} \mathrm{C}$, with light/dark cycle of $12 \mathrm{~h}$, with ad libitum water and food. Animals were divided in 4 equal groups, being:

- Group 1 (Placebo): submitted to sciatic nerve injury and treated with placebo;

- Group 2 (NM): sciatic nerve injury and treated with neural mobilization;

- Group 3 (LASER): sciatic nerve injury and treated with low-level LASER, $830 \mathrm{~nm}$, fluency of $4 \mathrm{~J} / \mathrm{cm}^{2}$, on the injury site;

- Group 4 (NM+LASER): sciatic nerve injury and treated with neural mobilization associated to low-level LASER.

\section{Experimental sciatic nerve injury protocol}

To produce sciatic nerve injury, all rats were anesthetized with intraperitoneal ketamine hydrochloride $(95 \mathrm{mg} / \mathrm{kg}$ ) and xylazine hydrochloride $(12 \mathrm{mg} / \mathrm{kg})$. Under anesthesia, they were submitted to trichotomy and incision parallel to right femoral biceps muscle, exposing the sciatic nerve. Following the model by Bennett $\& \mathrm{Xie}^{10}$, a compression around the sciatic nerve was applied in three different regions, with approximate distance of $1 \mathrm{~mm}$, using a 4.0 chromed catgut thread, reproducing sciatica on its pathway. Then, an external suture was performed and iodine was applied for asepsis.

\section{Low-level LASER therapy protocol}

For this therapy, animals were also anesthetized and LASER (Ibramed ${ }^{\circ}$ ) was previously checked as to its level, presenting wavelength of $830 \mathrm{~nm}$, fluency of $4 \mathrm{~J} / \mathrm{cm}^{2}$, emission power of $30 \mathrm{~mW}$, area deposited on tissue of $0.48 \mathrm{~J}$. Therapeutic technique was punctual and continuous, being the equipment positioned perpendicularly in a single point, specifically over the surgical incision. For such, animals were placed in prone position on a table for LASER application. This treatment was always applied by the same researcher and was applied to groups G3 and G4. For G1 (placebo), LASER was turned off and just positioned on the animals; treatment was applied in the $3^{\text {td }}, 5^{\text {th }}, 7^{\text {th }}, 10^{\text {th }}, 12^{\text {th }}$ and $14^{\text {th }}$ postoperative days (PO).

\section{Neural mobilization therapy protocol}

For neural mobilization with tension, an adapted intervention was used where rats were anesthetized according to previous description and therapy was applied to the right hind leg. Animals were placed in supine position, with hip flexed in approximately $70^{\circ}$, knee in maximum possible extension and ankle dorsiflexion until sensation of resistance to movement. The ankle was passively moved in planti and dorsiflexion, with approximately 30 movements during one minute. This procedure was always performed by the same researcher and was applied to G2 and G4. For G1 (placebo) the leg was just raised without planti and dorsiflexion movements and treatment was performed in the $3^{\text {rd }}, 5^{\text {th }}, 7^{\text {th }}, 10^{\text {th }}$, $12^{\text {th }}$ and $14^{\text {th }} \mathrm{PO}$. 


\section{Evaluation of nociception}

A test with digital alnalgesimeter, Von Frey filament-type, Insight ${ }^{\oplus}$ brand, was used to evaluate nociception. The equipment is an arm with a disposable polypropylene probe, with capacity to evaluate $0.1-1000 \mathrm{~g}$, connected to an amplifier box. To help animals' adaptation to the instrument, an evaluation simulation was performed one week before the injury. This way, filament was applied to the sciatic nerve injury site and to the plantar region of animal's right hind paw. To exert pressure at injury site, the animal was manually restrained and the filament tip touched the injury site until the animal removed the leg. To exert pressure in the right plantar region, the animal was kept in raised box with screen floor, the filament was positioned and pressure was exerted until right leg removal.

These evaluations were performed in the following moments: first evaluation (EV1) pre-injury; second evaluation (EV2) in the $3^{\text {rd }} \mathrm{PO}$, being performed before treatment; third evaluation (EV3) in the $4^{\text {th }} \mathrm{PO}$, before treatment; fourth evaluation (EV4) in the $7^{\text {th }} \mathrm{PO}$, before treatment; fifth evaluation (EV5) in the $10^{\text {th }} \mathrm{PO}$, before treatment; sixth evaluation (EV6) in the $14^{\text {th }} \mathrm{PO}$, before treatment; and seventh evaluation (EV7) in the $15^{\text {th }} \mathrm{PO}$, that is one day after finishing all treatments and evaluations. Two days after the last evaluation, animals were euthanized by decapitation in guillotine, being previously anesthetized.

\section{Statistical analysis}

Results were analyzed by the statistical test ANOVA, mixed model, with Bonferroni post-test, with significance level for both cases of $\mathrm{p}<0.05$, being calculated data mean and standard deviation.
This study was approved by the animal research Ethics Committee (CEUA) under protocol 002/2013.

\section{RESULTS}

Results of paw nociceptive evaluation have shown that with treatment, rats' nociceptive threshold has not increased. It was observed that: $\mathrm{F}(6 ; 144)=22 ; \mathrm{p}<0.001$, being the statistically significant difference found among evaluations, where EV1 values were higher than those for remaining evaluations. However, there has been no significant difference among groups (Table 1). Injury site evaluation has also shown that with treatment, rats' nociceptive threshold has not increased and it was observed that: $\mathrm{F}(3.1 ; 74.78)=30.4 ; \mathrm{p}<0.001$, with statistically significant difference between EV1 and remaining evaluations. There has also been no statistically significant difference among groups (Table 2).

\section{DISCUSSION}

This study has used a sciatic nerve compression model which mimics sciatica symptoms, aiming at evaluating the effect of lowlevel LASER, of neural mobilization and of their association on sciatica nociceptive threshold in rats. These experimental models for sciatic nerve compression of rats have been used to evaluate nociception due to the similar structure of the sciatic nerve of rats and humans ${ }^{11}$. According to our results, there has been no nociceptive pressure threshold increase of rats submitted to experimental sciatica model.

Literature has studies using separate techniques, which corroborate or not our results. One study has observed the effects of

Table 1. Nociceptive evaluation of right paw plantar region (Mean \pm SD)

\begin{tabular}{lcccc}
\hline & & \multicolumn{3}{c}{ Grupos } \\
Evaluations & Placebo & NM & LASER & NM+LASER \\
\hline AV1 & $73.21 \pm 10.37$ & $56.80 \pm 15.02$ & $67.14 \pm 12.94$ & $68.33 \pm 10.34$ \\
AV2* & $41.47 \pm 20.55$ & $46.61 \pm 16.45$ & $51.49 \pm 16.47$ & $44.33 \pm 9.38$ \\
AV3 $^{*}$ & $42.23 \pm 13.70$ & $33.37 \pm 5.09$ & $43.32 \pm 13.57$ & $44.87 \pm 6.37$ \\
AV4 $^{*}$ & $34.90 \pm 11.51$ & $40.66 \pm 16.10$ & $33.66 \pm 13.20$ & $41.37 \pm 9.08$ \\
AV5 $^{*}$ & $39.13 \pm 9.76$ & $30.94 \pm 6.77$ & $41.09 \pm 17.34$ & $37.28 \pm 9.16$ \\
AV6 $^{*}$ & $36.42 \pm 9.03$ & $34.57 \pm 11.66$ & $40.99 \pm 18.66$ & $37.32 \pm 6.71$ \\
AV7 $^{*}$ & $34.90 \pm 9.28$ & $28.9 \pm 12.04$ & $32.52 \pm 9.118$ & $42.75 \pm 17.20$ \\
\hline
\end{tabular}

${ }^{*}$ Significant difference as compared to AV1, regardless of the group.

Table 2. Nociceptive evaluation of injury site (Mean \pm SD)

\begin{tabular}{lcccc}
\hline & & \multicolumn{3}{c}{ Grupos } \\
Evaluations & Placebo & NM & LASER & $376.49 \pm 158.49$ \\
AV1 & $357.23 \pm 134.20$ & $351.66 \pm 130.68$ & $392.16 \pm 131.18$ & $250.18 \pm 113.38$ \\
AV2* & $271.13 \pm 165.23$ & $231.51 \pm 188.31$ & $242.54 \pm 133.18$ & $176.33 \pm 93.53$ \\
AV3 $^{*}$ & $202.85 \pm 94.36$ & $170.75 \pm 110.22$ & $199.23 \pm 111.05$ & $234.28 \pm 85.63$ \\
AV4 $^{*}$ & $244.56 \pm 107.44$ & $175.80 \pm 108.91$ & $197.94 \pm 76.51$ & $216.94 \pm 62.73$ \\
AV5 $^{*}$ & $235.80 \pm 82.60$ & $160.99 \pm 87.98$ & $206.42 \pm 88.20$ & $216.97 \pm 73.63$ \\
AV6 $^{*}$ & $219.90 \pm 70.10$ & $195.56 \pm 64.44$ & $250.59 \pm 53.97$ & $203.18 \pm 75.83$ \\
AV7 $^{*}$ & $226.90 \pm 47.79$ & $202.80 \pm 61.26$ & $206.33 \pm 62.05$ & \\
\hline
\end{tabular}

*Significant difference as compared to AV1, regardless of group. 
two low-level 830nm LASER doses on decreasing nociception of animals submitted to sciatica and it was observed that both LASER $(830 \mathrm{~nm})$ doses of $4 \mathrm{~J} / \mathrm{cm}^{2}$ and of $8 \mathrm{~J} / \mathrm{cm}^{2}$ were effective to decrease pain, being that functional incapacity test was used for evaluation (flinching time) ${ }^{12}$.

A different study has evaluated the influence of low-level AsGaAl LASER ( $830 \mathrm{~nm}$ with dose of $\left.20 \mathrm{~J} / \mathrm{cm}^{2}\right)$, in different irradiation sites, in crush injury of sciatic nerve branch (common fibular) of rats, by means of functional gait evaluation, being the treatment performed for 28 days, on spinal cord, on nerve site and on both (nerve and spinal cord). Functional sciatic index was used for evaluation and it was observed that LASER was able to accelerate and potentiate peripheral nerve regeneration process in rats in the $14^{\text {th }} \mathrm{PO}$ day both for the group treated in the spinal cord and the group treated in the injured nerve ${ }^{13}$.

So, when comparing results of previous studies with our study, using low-level $830 \mathrm{~nm}$ LASER with fluency of $4 \mathrm{~J} / \mathrm{cm}^{2}$, and evaluation performed with digital analgesimeter Von Frey type, both pressure applied to the injury site and to right hind paw plantar region have not shown the same effect since there has been no significant difference among groups, but only between EV1 and remaining evaluations of all groups, that is, there has been no nociceptive threshold increase.

In addition, one research was found in the literature evaluating the efficacy of neural mobilization and of static stretching to decrease nociception in Wistar rats submitted to experimental sciatica. Again, animals were evaluated by the functional incapacity test (flinching time), and for neural mobilization a protocol similar to our study was used. It was observed that both therapies were effective to decrease nociception, being neural mobilization the most effective ${ }^{14}$. This was not observed in our study because when evaluating rats' nociception, there has been no statistically significant difference among groups. But it is worth stressing that gender and animal model (female rats) were different in the above-mentioned study, and the evaluation was by pressure and not functional as in the above-mentioned studies.

Similar result was obtained in a nervous compression model, however with the median nerve of male rats, to observe the effects of neural mobilization in 1 and 3 minutes. Nociception was evaluated with digital analgesimeter Von Frey type and by nerve histomorphometric characteristics and it was observed that there has also not been statistically significant difference between groups, that is, neural mobilization was not effective to improve nociception and, histologically there has also not been nervous regeneration ${ }^{15}$.

Some authors report that a major factor to implement neural mobilization technique is to perform exercises until there is resistance?. However, it is important to note that animals were anesthetized, which is not the case with human beings who may verbally report any sign of discomfort, thus controlling the amount of force applied by the therapist. In the anesthetized animal, this verbal response is impossible and for this reason our results might have been limited. So, other studies could investigate the application of different passive force parameters on the animal limb.
No studies were found in the literature reporting the use and effects of both associated techniques, that is, low-level LASER and neural mobilization, being that in our study, the treatment with the associated techniques was also not effective. However, several factors may have contributed for such results, like the fact that the treatment was performed for a short time, being neural mobilization performed during one minute and LASER applied to a single point. So, we suggest further studies in this area, with longer mobilization times and different LASER wavelengths and doses which may contribute with professionals, regarding therapeutic resources to be indicated for a certain treatment.

\section{CONCLUSION}

Low-level LASER with wavelength of 830nm and fluency of $4 \mathrm{~J} /$ $\mathrm{cm}^{2}$, neural mobilization and the association of both techniques were not effective to increase nociceptive threshold to pressure of rats submitted to experimental sciatica model.

\section{ACKNOWLEDGMENTS}

To the National Council of Scientific and Technological Development $(\mathrm{CNPq})$ for the support with scientific initiation scholarship in the Affirmative Actions modality.

\section{REFERENCES}

1. Lana AD, Paulino CA, Gonçalves ID. Influência dos exercícios físicos de baixa e alta intensidade sobre o limiar de hipernocicepçáo e outros parâmetros em ratos. Rev Bras Med Esporte. 2006;12(5):248-54.

2. Câmara CN, Brito MV, Silveira EL, Silva DS, Simóes VR, Ponte RWF. Histological analysis of low-intensity laser therapy effects in peripheral nerve regeneration in Wistar rats. Acta Cirúrgica Bras. 2011;26(1):12-8.

3. Stafford MA, Peng P, Hill DA. Sciatica: a review of history, epidemiology, pathogenesis, and the role of epidural steroid injection in management. Br J Anaesth. 2007;99(4):461-73.

4. Hildreth CJ, Lynm C, Glass RM. Sciatica. J Am Med Assoc. 2009;302(2):216-7.

5. Piva JA, Silva VS, Abreu EM, Nicolau RA. Açóes da terapia com laser de baixa potência nas fases iniciais do reparo tecidual: príncipios básicos. An Bras Dermatol. 2011;86(5):947-54.

6. Santos FM, Silva JT, Giardini AC, Rocha PA, Achermann AP, Alves AS, et al. Neura mobilization reverses behavioral and cellular changes that characterize neuropathic pain in rats. Mol Pain. 2012;29(8):1-9.

7. Machado GF, Bigolin SE. Estudo comparativo de casos entre a mobilizaçáo neura e um programa de alongamento muscular em lombálgicos crônicos. Fisioter Mov. 2010;23(4):545-54.

8. Oskay D, Meriç A, Kirdi N, Firat T, Ayhan C, Leblebicioğlu G. Neurodynamic mobilization in the conservative treatment of cubital tunnel syndrome: long-term follow-up of 7 cases. J Manipulative Physiol Ther. 2010;33(2):156-63.

9. Oliveira Junior F, Teixeira AH. Mobilizaçáo do sistema nervoso: avaliaçáo e tratamento. Fisioter Mov. 2007;20(3):41-53.

10. Bennett GJ, Xie YK. A peripheral mononeuropathy in rat that produces disorders of pain sensation like those seen in man. Pain. 1988;33(1):87-107.

11. Gonçalves RB, Marques JC, Monte-raso VV, Zamarioli A, Carvalho LC, Fazan VP, et al. Efeitos da aplicaçáo do laser de baixa potência na regeneraçáo do nervo isquiático de ratos. Fisioter Pesq. 2010;17(1):34-9.

12. Bertolini GR, Artifon EL, Silva TS, Cunha DM, Vigo PR. Low-level laser therapy, at 830 $\mathrm{nm}$, for pain reduction in experimental model of rats with sciatica. Arq Neuropsiquiatr. 2011;69(2):356-9.

13. Souza FF, Andraus RA, Barbiere $\mathrm{CH}$, Mazzer N. Influência da irradiaçáo do laser na regeneração nervosa em diferentes locais de tratamento. Acta Ortopédica Bras. 2009;17(6):331-5.

14. Bertolini GR, Silva TS, Trindade DL, Carvalho AR. Neural mobilization and static stretching in an experimental sciatica model - an experimental study. Rev Bras Fisioter 2009;13(6):493-8.

15. Marcioli MA, Coradini JG, Kunz RI, Ribeiro LD, Brancalhão RM, Bertolini GR. Nociceptive and histomorphometric evaluation of neural mobilization in experimental injury of the median nerve. Sci World J. 2013;11(1):1-6. 